\title{
Protein Tyrosine Phosphatase Type IVA 3
}

National Cancer Institute

\section{Source}

National Cancer Institute. Protein Tyrosine Phosphatase Type IVA 3. NCI Thesaurus. Code C151406.

Protein tyrosine phosphatase type IVA $3(173 \mathrm{aa}, \sim 20 \mathrm{kDa})$ is encoded by the human PT P4A3 gene. This protein plays a role in tyrosine phosphatase activity that promotes cell cycle progression. 